\title{
PEDAGOGY
}

\section{LEARNER-CENTERED APPROACH TO BUILDING LEXICAL COMPETENCE IN SPEAKING FOR PROSPECTIVE EXPERTS OF HOSPITALITY AND RESTAURANT SERVICE}

\author{
Senior Lecturer, Iryna Skril \\ Ukraine, Lviv, Lviv Professional College of Hospitality, Tourism and Restaurant Service; \\ Head of Department of Foreign Languages
}

DOI: https://doi.org/10.31435/rsglobal_ws/31052019/6524

\section{ARTICLE INFO}

Received: 17 March 2019

Accepted: 26 May 2019

Published: 31 May 2019

\section{KEYWORDS}

learner-centered approach, communicative activities, teaching methods, hospitality and restaurant service.

\begin{abstract}
The article deals with the learner-centered approach to building lexical competence in speaking for prospective experts of hospitality and restaurant service. According to modern methodical principles the main aspect of teaching foreign languages are made on a learner-centered approach. Activities often create a sense of community within the class. The such as meeting the guest in the restaurant, showing the guest to the table, taking an order, dealing with complaints are held. From the analysis, it was concluded that learner-centered approach that developed the speaking skill through the realization of meaningful and authentic tasks.
\end{abstract}

Citation: Iryna Skril. (2019) Learner-Centered Approach to Building Lexical Competence in Speaking for Prospective Experts of Hospitality and Restaurant Service. World Science. 5(45), Vol.3. doi: 10.31435/rsglobal_ws/31052019/6524

Copyright: (C) 2019 Iryna Skril. This is an open-access article distributed under the terms of the Creative Commons Attribution License (CC BY). The use, distribution or reproduction in other forums is permitted, provided the original author(s) or licensor are credited and that the original publication in this journal is cited, in accordance with accepted academic practice. No use, distribution or reproduction is permitted which does not comply with these terms.

Introduction. Modern methodology states the ideas and principles in teaching such as recognition of paramount learning process and access to information; the value of cooperation including the usage of dialogues, polylogues, improvisation and role play as the main form of work; recognition of the equality of cognitive and creative opportunities for all students, and conscious students participation in learning; active position of a student in learning; communicative principles, which envisages the construction of the learning process as a model of the real communication process; taking into account individual-psychological features of the student in learning.

All this principles are interrelated. The implementation of each principle alone can not lead to some efficiency studies, but is much more effective introducing of all guidance system as a whole.

Important role in learning foreign languages play the perception processes. Individual features of perception display in its completeness, accuracy, speed. They are characterized by integrity, emotionality if students attention is attracted by the facts (synthetic type), or predominant analysis when attention is directed to the meaning and explanation of facts (analytical type), sometimes observation and description of facts are combined with their explanation (analytical-synthetic type). This shows the need for individualization of means and learning forms, learner-centered approach.

It may be used for the training of for prospective experts of hospitality and restaurant service, because students find themselves in the real situation which may occur to them in their future profession.

Students learn how to behave and what to do, and express their thoughts and knowledge in English. The professions such as restaurant manager, receptionist, event coordinator, hotel manager, sales consultant are very popular now, and they need special attention. And through communicative activities of learner-centered approach the students have a great opportunity to combine and practice 
their professional skills and English language. Students easily speak in class when there is a good atmosphere, the language is suitable for the level, the topic is appropriate and the tasks are apposite and well-organized [2]. And very often the lessons are held in the restaurant or hotel (where they have practice), so the students can really feel the situation in real atmosphere.

The reviewed literature shows that the formation of lexical competence and similar communicative activities have been studied by a large number of researches (O. Bihych, V. Buhbinder, I. Zadorozhna, L. Morska, N. Mykytenko, N.Minina, S. Nikolaieva, Ye. Passov, I. Semeriak, O. Tarnopolsky, D. Tereschuk). The works dedicated to learner-centered approach have been described by R. Baldauf, H. Brown, J. Cornelius-White, K. Moni, S. Schiller. The technologies of teaching foreign language have been analyzed by scholars such as I. Bim, M. Gredler, R. Milrood, E. Polat, G. Neuner, J. Richards, W. Rivers, E. Rogers, M. West and others. However, the development of prospective experts' of hospitality and restaurant service speaking skills by using learner-centered approach has not achieved sufficiently thorough consideration.

Purpose of the study: to analyze the learner-centered approach to building lexical competence in speaking for prospective experts of hospitality and restaurant service.

Research results. In the learner-centered approach means teaching students a foreign language in a class with a common program, but with their individual and psychological features. It is determined such basic tasks and goals of learner-centered approach:

- filling in gaps in initial level of student's knowledge of foreign language, and timely removal of the new gap, if such appears;

- developing intellectual outlook, psychological processes and qualities of student personality, which play a leading role in the learning of foreign language;

- activating and stimulating learning and educational activities of students.

It may be practically implemented by using different kinds of individualization. The highest level of interest and success in studying a foreign language is achieved at the ratio of external and internal motivation as $70 \%$ to $30 \%$, so it comes to the so-called motivating individualization.

Regulated individualization is a directed on a teacher taking into account the actual level of knowledge and skills of students at each stage of the educational process, the possibility of simplification and variation of tasks for the less prepared students and complications for well trained and interested in foreign language students. The technique also implies reproduction and acquirement of social experience, which promotes human behaviour formation and enhancement [3, p. 333].

Changes in education require a different approach to learner-centered teaching. At the forefront comes forward synergy (cooperation) in the learning process. Human beings are social beings who need to communicate to each other [4].

It is clear that training will only be productive, when it is accomplished in cooperation and collaboration with student and teachers, in certain types of work may replace cooperation between students. This education model is based on the need for active positions in student learning, teacher - a leader and a student - an employee who takes an active position.

Synergetic education as individual-oriented provides the use of such general methodological principles as the principle of individualization of education:

- knowledge mastering by the students must pass in rate of their abilities and only minimum is general obligated;

- talanted students should receive the maximum opportunity to develop their capabilities; close to students:

and the principle of maximal approaching of educational material to the realities of life,

- this will promote understanding of the knowledge importance and development of appropriate conscious motivation.

Many strategies and teaching methods contribute to the implementation of these principles in practice, and among them such as:

- debates

- role playing game

as methods of interaction (synergistic) teaching

- discussion

- role playing

- games

- simulations

as methods based on experience 
Games and simulations have become an essential part of language and science education since the late 1950s [1, p. 571], and are considered to be widely used techniques of the communicative approach to language teaching and learning. A role play always implies simulation of a situation, thus, it is sometimes referred to as "simulation," "game," "role-play," "simulation-game," "role-play simulation," and "role-playing game" [8]. Role plays are based on the principles of collective work, practical utility, competition, maximum participation of each student and unlimited creative activities [7, p. 334]. According to O. Tarnopolsky, simulations are mostly believed to be linked to professional content matter - including the content of professional communication in the target language, and they focus not so much on communication situations but more on the functions of professional activities being modelled in them [6, p. 30, 36].

Both methods include communicative activities to build lexical competence in speaking, which have certain advantages, such as:

- related to the activity in which students receive a role they should play;

- used to learn about the processes that occur in other groups, or feeling other participants in the game;

- teacher only gives students a task and offers to play roles, students choose how to do this;

- students really like the opportunity to be in someone's place;

- creates a favorable opportunity for discussion.

The quality of mastering a foreign language activity by a student is largely due to the influence of individual psychological processes. At the present stage of development methodologies it is shown the need of consciously mastering of foreign language skills and abilities with support upon the thought processes of analysis and synthesis. Acquired by the following skills and abilities are more flexible and stable. Thinking is characterized by different features such as independence, depth of understanding and speed. Thinking works in unity with the speech. The presence of individual differences in thinking requires the use of different methods of teaching. Some of the possible teacher roles are:

- Facilitator - students may need new language to be 'fed' in by the teacher. If rehearsal time is appropriate the feeding in of new language should take place at this stage.

- Spectator - The teacher watches the role-play and offers comments and advice at the end.

- Participant - It is sometimes appropriate to get involved and take part in the role-play yourself.

Learner-centered education broadly encompasses methods of teaching that shift the focus of instruction from the teacher to the student. The teacher still has an authoritative role, but the students and the teachers play an equally active part in the learning process. The primary goal of the teacher is to coach and facilitate students' learning and comprehension of the subject material. Here there are some characteristics of learner-centered learning:

Students work harder than teachers: In most classes, teachers are doing too many learning tasks for students, ask the questions, add detail to their answers. It is necessary to offer the examples and organize the content. They do the preview and the review. Teachers should extend part of those responsibilities to the learners.

Students learn from students as well: Students can learn from and with each other. Certainly the teacher has the expertise and an obligation to share his/her knowledge, but teachers can learn from students as well.

Students learn more by experiences and active involvement: Teachers nurture students' natural curiosity as students ask questions to complete the assignments.

Students apply new learning to real-life, authentic experiences: Classes focus more on skills that we can use in real-life. Classes that to not have real-life application hardly ever motivate students to engage in meaningful learning.

Students receive frequent directed, and timely feedback: As students complete some assignments, teachers typically ask learners or groups of learners to talk and compare their results with peers.

Students are encouraged to explain material to themselves and others: If students are creative enough, they can think about ways to introduce a topic that involves the students in the process.

Students regularly engage in communication: Students need to communicate with each other and that is why this approach to teaching bring more benefit than teacher-centered instruction. Students can introduce a topic, receive feedback from others and complete assignments collaboratively.

Students know what they are learning and why: Teachers who have adopted a learnercentered approach state what they expect their learners to accomplish by the end of the class and make sure they give clear instructions about the behavior and dynamics he/she expects to see in class. 
Students use personalized technology to produce: Students learn by doing so technology, specially mobile phones and tablets which are easier to handle and use than computers can really boost engagement and motivation. If teachers want their students to create, one of the cheapest and engaging ways is using the resources available on the internet.

A higher degree of engagement: Students standing up and talking to others to complete some assignments creates more opportunities to talk and learn from others. Since receptive skills are the ones necessary to learn new things, listening to others is crucial for the successful repetition of new vocabulary.

In language acquisition, speaking and trying to communicate with others are considered the principal focus as well as in task- based learning [5]. Classification of tasks is based on conversations and interaction. This classification includes jigsaw tasks, information-gap tasks, problem-solving tasks, decision-making tasks and opinion exchange tasks. Here some examples of activities to provide suitable opportunities for productive use of the language:

I. Terminal Objectives:

Students will be able to identify the nature of a conversation between two people, suggest reasons for it and give advice to the participants in it.

Students will be able to share information about the promotion practices of one hotel and be able to give an opinion about the suitability of the practices.

Enabling Objectives:

Students will be able to identify the use of opposites in the conversation. information.

Students will be able to use the indirect expression, "X said/told/asked that..." to share

Students will list positions in a hotel, from lowest to highest.

Students will be able to explain the meaning of the word "promote".

Students will be able to state good and bad reasons for promotion in a hotel, including opposites (i.e. "He works hard" and "He is lazy.")

Warm-Up: song "Hello, Goodbye":

Pre-listening activity:

Do the students know the group "The Beatles"? If yes, where are they from? Are they a new group or an old group? What songs do they sing? If no, state briefly that they are an English group that wrote many songs that are still popular in the 1960's and 70's.

Tell the group they are going to hear a Beatles song. The man who is singing is not happy. Listen and then be ready to tell me why the man is not happy.

Play the song once (it repeats.)

Post-listening activity

After listening, ask why the man is not happy. How do you know? Brainstorm the opposites used in the song - list on board. (If necessary, put the printed lyrics up on the screen.) Model "He says that..." orally and on the board. Leave the model on the board. on board.

Why do you think the man and his (girl)friend are (arguing/fighting/disagreeing)? List ideas

Pairwork: You are the man's friends. You have two minutes to decide what advice you will give him. Debrief in the large group: What will you tell your friend? You will tell him that...

Jigsaw Activity: "The Promotion"

Go through the vocabulary list, asking students to give the meaning of each word. NB - sales rep - ask for definition of sales representative, then present sales rep as a common abbreviation.

Break class into four groups according to ability level. Give parts B and C to the weakest groups and part $\mathrm{D}$ to the strongest group. Each group will read their part silently, then discuss it to make sure that everyone agrees on the meanings. Some Ukrainian will be OK during this activity.

Resort groups so that each new group has members from Groups A, B, C and D. Each member of the new groups will tell each other their part of the story. whole class.

Hand out the questions to be answered within each group. Check answers orally with the

Refer to the "He said that..." indirect speech model left on the board earlier. Ask students for another couple of examples. Hand out the grammar practice page; give them two minutes to do it as a group and check it orally (write the answers on the board.)

Discussion question: full group - Why was Andy promoted so quickly? Is this a good or bad reason? Brainstorm good and bad reasons for promotion. Do you see any opposites? What other opposites can you think of for these reasons for promotion? 
II. Terminal Objectives:

Students will be able to identify expressed emotions and the reasons for them.

Students will be able to work cooperatively to plan a trip that meets a client's needs.

Enabling Objectives:

Students will be able to name common emotions.

Students will be able to explain how they are able to determine what emotion is being expressed.

Students will identify evidence in a context that explains the reasons for an emotional state.

Students will suggest possible solutions to interpersonal emotional problems.

Students will be able to elicit from travellers information about reasons for travel.

Students will be able to elicit information from a traveller that allows them to plan a suitable itinerary.

\section{Activities:}

1. Teacher will ask students how they are feeling today, as a group. Expected response: fine. Teacher will put feelings untitled poster on screen. How are these people feeling today? Students will make suggestions. After suggestions have been made for all images, teacher will put feelings titled poster on screen. Students will practice saying terms. Teacher will define any terms that are not understood. What other feelings can you think of that are not on the poster?

2. Brainstorm around feelings poster: What makes you feel

3. Focus on "sad." There are many ways of feeling sad that have their own names. Use reasons for sadness previously stated by students to bring out sadness-related terms such as hurt and lonely. Use Google images photofile to stimulate suggestions.

4. "Song for a Winter's Night"

1) What feelings does the title of the song give you? Why?

2) Listen to the opening music. How does it make you feel? that way?

3) As you listen to the song, try to decide what the man is feeling. Why do you think he feels

4) Hand out the lyrics and play the song again. As you listen, circle all the words that suggest the man's feelings. Do you still believe that he feels that way?

5) Pairs: Answer the following questions:

- Where is the man? What makes you think so?

- What is his problem?

- What should he do about his problem?

6) Full group discussion: debrief questions. Suggestion that either he go to visit his girlfriend or have her visit him should be offered or elicited. What kind of trip would this be - business? leisure? family? other?

5. Divide class into groups of three or four: one or two travel agents, the man and the woman. Decide where they will meet, and plan the trip. Each group will report on their plan in the last ten minutes of the class.

Conclusions. Learner-centered approach can help students become more interested and involved, not only learning about the material, but learning also to integrate the knowledge in action, by addressing problems, exploring alternatives, and seeking novel and creative solutions. It is the best way to develop the skills of initiative, communication, problem-solving, self-awareness, and working cooperatively in team. It can be effectively used for the speaking skills development of prospective experts of hospitality and restaurant service. The involvement of the participants can create both an emotional and intellectual attachment to the subject matter at hand. The role the teacher assumes is different. It is more of a facilitator than the person who does most of the talking. If a skillful teacher has accurately matched the problem situation to the needs of his/her group, the solving of realistic life problems can be expected. In case of using learner-centered approach to build lexical competence in speaking will be beneficial for prospective experts of hospitality and restaurant service.

\section{REFERENCES}

1. Gredler M. E. Games and simulations and their relationship to learning/ M. E. Gredler// Handbook of Research on Educational Communications and Technology/ D. H. Jonassen (Ed.). - Mahwah, NJ: Lawrence Erlbaum Associates, 2004. - P. 571-582

2. Harmer J. The Practice of English Language Teaching / J. Harmer. - $3^{\text {rd }}$ ed. - [S. 1.]: Pearson Education Limited, 2001. - $371 \mathrm{p}$.

3. Medodyka navchannia inozemnych mov i kultur: teoriia i praktyka [Methodology of teaching foreign languages and cultures: theory and practice]: pidruchnyk dlia stud. klasychnykh, pedahohichnych i 
linhvistychnykh universytetiv / Bihych O. B., Borysko N.F., Boretska H.E. ta in. / za zahaln. red. S. Yu. Nikolaievoii. - K.: Lenvit, 2013. - 590c.

4. Reddy, M. S., Mahavidyalaya, P., \& Hyderabad, K. Importance of English Language in today's world. International Journal of Academic Research. - 2016. - P. 179- 184.

5. Richards, J., \& Rodgers, T. Approaches and Methods in Language Teaching. Cambridge University Press. 2014. - 410p.

6. Tarnopolsky O. Constructivist blended learning approach to teaching English for Specific Purposes. London: Versita, 2012. - $254 \mathrm{p}$.

7. Teoriia i praktyka formuvannia inshomovnoi profesiino oriientovanoi kompetentnosti v govorinni u studentiv nelinhvistychnyh spetsialnostei [Theory and practice of formation of foreign language professional-oriented competence in speaking among students of non-linguistic specialties]: kolektyvna monohrafiia za zah. i nauk. red O. B. Bihych / O. B. Bihych, L. V. Bondar, M. M. Voloshynova, L. O. Maksymenko, O. M. Ohui, I. O. Simkova, Ya. V. Okopna. - Kyiv: Vyd. tsentr KNLU, 2013. - 383 p.

8. Tompkins K. P. Role Playing/Simulation/ K. P. Tompkins // The Internet TESL Journal. - 1998. - Vol. 4, No. 8 [Electron resource]. - Access mode: http://iteslj.org/Techniques/Tompkins-RolePlaying.html 